\title{
DR. F. W. R. HORSTMANN
}

\author{
DOOR
}

FRED. OUDSCHANS DENTZ

In de Encyclopaedie van Nederlandsch West-Indiē wordt op blz. 366 een en ander medegedeeld over den geneesheer Friedrich Wilhelm Rudolf Horstmann ${ }^{1}$ ), die in 1794 te Hildesheim (Hanover) geboren is, in Göttingen in de geneeskunde studeerde, en zich in 1818 te Paramaribo vestigde, waar hij met zijn uitgebreide praktijk een aanzienlijk fortuin verdiende.

Hieraan kan ik uit een ingesteld onderzoek het volgende toevoegen. Dr. Horstmann trad op vrij laten leeftijd, nl. op 14 Maart 1836, met een Surinaamsch meisje in het het huwelijk. Hij huwde op 41-jarigen leeftijd de 19-jarige Johanna Catharina Heidweiler, behoorende tot de Hervormde Gemeente. Haar moeder was een weduwe Stuger. Hij zelf was Luthersch.

Het echtpaar had drie kinderen: een jongen, Leopold Andreas, geboren 30 Sept. 1848, die reeds binnen het jaar op 19 Sept. 1849 overleed, een dochter Sophia Henriette, geboren 28 Februari 1850; zij huwde een planter, den gezagvoerder van plantage „Berlijn”, Willem Ephraïm Gerard Lehnkering, geboren te Oudenbosch in Noord-Brabant, zoon van Gerrit Henry Grauwich Lehnkering en Emma Johanna Pichot, wonende te St. Oedenrode. Lehnkering overleed 4 Juni 1885; zijn echtgenoote was reeds 17 Augustus van het vorige jaar overleden. De tweede dochter van Horstmann, Louisa Maria, geboren 16 October 1838, stierf ongehuwd in 1891, oud 52 jaar.

Horstmann, die een groot natuurvriend was, en tal van botanische en zoölogische verzamelingen aanlegde, trok in 1840, na zijn praktijk te hebben opgegeven, naar het binnenland, maar keerde wegens ziekte naar Paramaribo terug.

Hij bereikte een hoogen leeftijd en blies op 26 October 1864 des

1) Pulle noemt hem F. W. Hostmann op blz. 167 Enc. Zie ook Bulletin Kol. Museum no. 38. 
avonds 9 uur den laatsten adem uit. Hij woonde in de Heerenstraat A. 72 tegenover den Apotheker Van Amson. De weduwe Horstmann-Heidweiler overleed in 1872 te Paramaribo. Zijn plantages droegen de namen van „Hanover” aan de Parakreek en „De twee kinderen" aan de Surinamerivier.

In 1843 had hij aan den gouverneur een uitgebreide memorie ingediend betreffende de kolonisatie met Europeanen. Dit geschrift en latere bemoeiingen zouden tot een briefwisseling tusschen het koloniaal gouvernement en het departement van Koloniën hebben geleid, waarop een betoog gevolgd is van den minister van Kolonien Mr. Baud aan den Koning, welke tot de kolonisatie aan de Saramacca aanleiding heeft gegeven.

Er overleed op 9 Juli 1885, ongehuwd, een planter te Paramaribo, genaamd Johann Heinrich Horstmann, geboren te Hunteberg (Hanover). Of deze familie van den geneesheer was, kan niet worden nagegaan. De naam Horstmann wordt somtijds Hostmann geschreven. 